\title{
KEBERLANJUTAN SIMBOL ETNISITAS KOMUNITAS JAWA WONOMULYO DI SULAWESI BARAT
}

Javanese Community Ethnic Symbols and its survivals in Wonomulyo, West Sulawesi

\author{
Susdiyanto \\ Universitas Islam Negeri Alauddin Makassar \\ JL Sultan Alauddin No.36 Samata-Gowa \\ Email: susdi.yanto@yahoo.com
}

\begin{abstract}
Abstrak
Penelitian ini bertujuan untuk mengungkap masalah keberlanjutan simbol etnisitas komunitas Jawa di kantong kolonisasi Wonomulyo, Sulawesi Barat. Metode pengumpulan data adalah observasi, wawancara, dan studi dokumen. Data dianalisis secara kualitatif. Hasil penelitian menunjukkan bahwa sikap komunitas Jawa Wonomulyo yang menjunjung nilai-nilai budaya yang mengedepankan harmonitas dalam hubungan interpersonal dan sikap keberagaman yang toleran ternyata dapat menjadi faktor pendukung terciptanya integrasi sosial antar etnis. Pranata-pranata tradisonal dan simbol-simbol etnisitas tetap fungsional meskipun telah terjadi perubahan seiring dengan perjalanan waktu pada komunitas Jawa di Kantong Kolonisasi Wonomulyo, Sulawesi Barat.
\end{abstract}

Kata kunci: sustatnabilitas, simbol, etnisitas

\begin{abstract}
The study aims to investigate the survivalof Javanese community ethnic symbol in Wonomulyo. The data were colected through direct observations, structured and free interviews. Document reviews were also used to obtain secondary information. The data then were analysed using qualitative method. The study shows that Javanese people in Wonomulyo put cultural values forward to maintain harmony in interpersonal relationship with others. Thislocal wisdom has facilitatedeasier social integration and ensuresthat acculturation with local people tradition iswide open and possible. Traditional wisdom and ethnic symbols are still maintained and well functioned although has relatively changed.
\end{abstract}

Keywords: survival, symbols, ethnicity

\section{PENDAHULUAN}

$\mathrm{M}$ obilitas penduduk Jawa keluar pulau berhubungan erat dengan kebijakan pemerintah koionial Hindia Beianda dalam menjalankan politik etis (ethiche politiek). Suatu politik balas budi pemerintah koionial Hindia Beianda atas utang kehormatan pada penduduk negeri jajahannya. Pelaksanaan politik etis dimulai tahun 1900, dengan semboyan edukasi, irigasi, dan emigrasi. Emigrasi kemudian menjadi kolonisasi pada tahun 1905, dan merupakan cikal bakal mobilitas penduduk Jawa ke luar pulau secara berkelompok dalam bentuk transmigrasi (Levang, 1997:8-9).
Menurunnya tingkat kesejahteraan penduduk pedesaan Jawa mendorong Conrad Theodore van Deventer, seorang anggota Raad van Indie di tahun 1899, untuk menulis De Gids dengan tajuk Een Eereschuld. Inti tulisannya menghimbau pemerintah kerajaan Beianda untuk melakukan upaya-upaya yang dapat membantu memperbaiki kehidupan rakyat di Pulau Jawa. Selain tulisan Deventer, karya E.D. Dekker dalam Max Havelar yang ditulis tahun 1860 banyak mengisahkan penderitaan rakyat negeri jajahan. Kritik-kritik inilah yang melatarbelakangi munculnya Etische Politiek di Indonesia (Karim: 2006). Program pemindahan penduduk terutama yang berada pada daerah Jawa, Madura, dan Bali terkait langsung dengan tekanan ekonomi yang dialami oleh penduduk negeri 
jajahan. Tanah-tanah di luar Jawa dianggap memiliki potensi yang besar bagi pengembangan usaha tani. Selain alasan kesejahteraan, pelaksanaan program kolonisasi juga didasarkan atas pertimbangan demografis, yaitu untuk mengurangi ketimpangan distribusi penduduk di pulau-pulau dalam wilayah pemerintahan Hindia Belanda (Andi-Lolo, 1986).

Beberapa daerah di Sulawesi Selatan dan Barat yang pernah dijadikan tujuan kolonisasi di antaranya adalah Bungi dan Paria di desa Sidomulyo (1937), Mapilli (1937) di Teluk Mandar, Masamba-Malili (1938) dengan desa kolonisasi Kalaena dan Tamuku di daerah Teluk Bone, Muna (1938) di Pulau Muna, serta Lamasi (1940) di sebelah utara Palopo. Tidak semua daerah tujuan kolonisasi di Sulawesi Selatan dan Barat dapat berkembang menjadi kantong pemukiman orang Jawa. Dua daerah yang kemudian berkembang sebagai daerah pemukiman dengan ciri khas ke"jawa"an adalah kolonisasi Mapilli yang kemudian dikenal dengan kolonisasi Wonomulyo, serta Palopo dengan kantong kolonisasi Lamasi dan Bone-Bone, sedangkan keempat wilayah kolonisasi lainnya Bungi, Paria, Tomuko, dan Tamuk tidak mengalami perkembangan yang berarti. Bahkan Bungi dan Paria sampai saat ini, tidak menyisakan bukti-bukti sebagai daerah yang pernah dijadikan tujuan kolonisasi (Swasono \& Masri: 1986).

Secara tradisional, orang Jawa termasuk suku bangsa yang memandang daerah di luar wilayah budaya mereka dengan pandangan yang negatif. Ranah budaya orang Jawa terbagi menjadi empat tingkatan yaitu nagara, nagara agung manca nagara, dan pesisir. Nagara adalah pusat atau inti dari budaya Jawa, karena itu nagara menjadi acuan bagi orang Jawa yang berada di luar wilayah itu. Nagara dipandang sebagai wilayah khusus yang mempunyai sistem sosial tersendiri dan masyarakat yang berdiam di wilayah itu dipandang paling halus dan paling tinggi strata sosialnya. Segala model kehidupan nagara dipandang sebagai acuan dalam etika kehidupan, bahasa, adat istiadat, bentuk rumah, dan berbagai kehidupan sosial lainnya. Meskipun nagara, nagara agung, manca negara, dan pesisir mempunyai karakteristik yang berbeda-beda secara konseptual, namun keempat wilayah tersebut dipandang sebagai satu kesatuan dalam budaya Jawa (Soemardjan, 1996). Selain keempat wilayah tersebut, Sairin (2002) mengemukakan satu wilayah lain yang disebut sabrang yakni wilayah yang secara konseptual dianggap sebagai daerah yang berada di luar ranah budaya Jawa (Sairin, 2002).

Mulder (1999) mengemukakan bahwa sikap yang dianggap menonjol pada orang Jawa adalah ketergantungannya pada masyarakat. Hierarkhi nilai-nilai yang diyakini oleh orang Jawa yaitu manusia Jawa tunduk kepada masyarakat, sebaliknya masyarakat tunduk pada kekuatan-kekuatan yang lebih tinggi dan halus, yang memuncak ke Tuhan. Dalam pandangan Mulder mengenai manusia Jawa ini, ter dapat jenjang struktural yang bersifat emanatif yang kemudian mengerucut serta mendudukkan posisi manusia sebagai sebuah mikro kosmos (jagad cilik) yang merupakan cerminan serta pantulan makro kosmos atau alam semesta yang sering disebutnya oleh orang Jawa dengan istilah jagad gede. Soelaiman (1998) mengemukakan bahwa sikap orang Jawa terhadap waktu dapat dilihat orientasinya terhadap masa depan, menunggu waktu yang baik, bersifat kekinian, tenggelam dalam zaman keemasan. Waktu berjalan melingkar, luwes dan mulur mungkret seperti gelang karet.

Dalam berbagai aktivitas orang Jawa selalu mencari hari baik dengan cara menghitung nilai hari dan nilai pasarannya. Berdasarkan sikap yang demikian, muncul semboyan alon-alon waton kelakon bukan alon-alon asal kelakon. Akibatnya, muncul kesan bahwa orang Jawa itu malas dan kurang menghargai waktu. Van den Bosch dalam melaksanakan sistem tanam paksa, juga memerlukan pengabsahan moral dan mitos tentang citra masyarakat Jawa yang malas. Bosch berdalih bahwa : (1) tanpa tanam paksa, pemerintah tidak dapat mengirimkan keuntungan yang besar ke Belanda, dan (2) karena sikap malas yang dimiliki masyarakat Jawa, sehingga mereka tidak mampu bekerja secara bebas dan selalu harus dipaksakan (Alatas, 1988).

\section{Tinjauan Pustaka}

Penelitian yang dilakukan baik oleh Lukman (2000) dan Hamzah (2000) pada komunitas Jawa di Wonomulyo Polewali Mamasa juga menunjukkan kecenderungan yang serupa yakni keterikatan orang Jawa terhadap adat istiadat leluhurnya meskipun mereka telah tinggal jauh dari daerah asalnya dalam rentang waktu yang relatif lama dengan lingkungan sosial yang sangat beragam. Kajian Lukman (2000) yang mengkhususkan pada pemertahanan Bahasa Jawa bagi warga transmigran Jawa menunjukkan, mereka umumnya masih mempertahankan bahasa Jawa sebagai bahasa leluhur mereka untuk berkomunikasi. Meskipun demikian bahasa Jawa yang berkembang di antara mereka adalah bahasa Jawa kasar (ngoko). Demikian pula penelitian yang dilakukan Hamzah (2000), yang membandingkan 
pola asuh anak pada etnik Jawa migran dan etnik Mandar menunjukkan bahwa pola asuh anak dipengaruhi oleh budaya ibu. Oleh karena itu, pola asuh anak pada etnik Jawa migran juga akan dipengaruhi oleh budaya Jawa.

Komunitas Jawa di Wonomulyo yang terbentuk sejak kurang lebih 74 tahun yang lalu, sampai saat ini masih mampu menunjukkan karakteristik sosial dan budayanya sebagaimana layaknya sebuah desa di Pulau Jawa. Komunitas Jawa Wonomulyo seolaholah tidak terpengaruh oleh lingkungan sosial dan budaya yang mengitarinya. Masih sering terdengar ungkapan "pergi ke kampung Jawa" bila yang dituju adalah Wonomulyo. Ungkapan tersebut dapat dibenarkan karena secara faktual desa-desa Jawa yang tergabung dalam Kecamatan Wonomulyo masih sangat kuat menunjukkan karakteristiknya sebagai kampung Jawa. Sehubungan dengan uraian di atas, masalah pokok yang menarik untuk diteliti mengenai orang Jawa di Wonomulyo adalah mengapa simbol-simbol etnitas kejawaan di daerah ini masih dapat bertahan. Selanjutnya, penelitian ini bertujuan untuk mengeksplorasi faktor-faktor yang mempengaruhi eksistensi simbol-simbol etnisitas komunitas Jawa di Wonomulyo yang masih bertahan hingga saat ini, meskipun dikelilingi oleh tradisi dan budaya berbeda.

\section{Metode Penelitian}

Penelitian ini menggunakan pendekatan kualitatif. Teknik pengumpulan data meliputi observasi, wawancara, dan dokumentasi. Metode observasi adalah observasi partisipatif, di mana peneliti mengamati secara langsung aktivitas masyarakat yang menjadi fokus penelitian yakni simbol-simbol etnisitas komunitas Jawa di kantong kolonisasi Wonomulyo. Proses interaksi, adaptasi, dan aplikasi nilai-nilai sosial budaya dalam lingkungan sosialnya serta perubahan beberapa aspek kehidupan yang terjadi pada komunitas Jawa di Wonomulyo juga menjadi sasaran pengamatan. Demikian pula pengamatan langsung digunakan untuk memperoleh data mengenai gaya bangunan rumah, tata ruang pemukiman, gaya bahasa, gaya pakaian, jarak sosial antar lapisan masyarakat, dan relasi sosial diantara mereka. Hal ini dapat digunakan sebagai bahan untuk membantu menentukan kadar keberlanjutan simbol-simbol etnisitas dan karakteristik sistem sosial budaya Jawa yang berlaku di kantong kolonisasi Wonomulyo.

Metode wawancara adalah wawancara mendalam (in-depth interview) dan wawancara bebas. Wawancara mendalam dilakukan terhadap informan dan informan kunci. Teknik dokumentasi digunakan untuk menelusuri dan menelaah dokumen-dokumen penting menyangkut kehadiran dan terbentuknya komunitas desa Jawa di Wonomulyo serta seluruh tata kehidupan mereka yang mungkin terdokumentasikan secara tertulis, baik yang terdapat di lembaga-lembaga pemerintah, masyarakat, maupun individual.

\section{PEMBAHASAN}

\section{Bahasa Jawa di Tanah Mandar yang Sedang Berubah}

Masyarakat yang berada di desa-desa Jawa Kecamatan Wonomulyo saling berinteraksi, bergaul, dan berkomunikasi dengan beragam kelompok etnik lain yang masing-masing memiliki bahasanya sendiri. Dalam suasana demikian, masyarakat Jawa menggunakan bahasa Indonesia sebagai bahasa pengantar atau bahasa etnik tertentu sesuai situasi dan kondisinya. Bahasa Indonesia menjadi bahasa resmi pergaulan antar etnik dan bahasa yang digunakan pada lembaga-lembaga formal. Hal ini memungkinkan orang-orang Jawa di Wonomulyo menggunakan multibahasa dalam berkomunikasi dengan lingkungan sekitarnya. Penggunaan multibahasa bagi orang-orang Jawa menyebabkan perhatian mereka terbagi untuk sejumlah bahasa yang harus digunakan. Kenyataan inilah yang menyebabkan munculnya beragam gaya bahasa, perubahan, dan penghayatan terhadap bahasa Jawa sebagai simbol etnik yang sarat dengan nilai-nilai dan norma-norma budaya Jawa menjadi berubah. Pada akhirnya, perubahan tersebut akan mempengaruhi pengetahuan dan pengamalan unggah-ungguh dalam berbahasa Jawa, baik secara lisan maupun tulisan. Misalnya, sebuah iklan layanan masyarakat yag berada di depan pasar Wonomulyo menggunakan Bahasa Jawa dengan ejaan yang tidak baku: "Ayo mas dipun bayer pajak'e dinggo bangun daerah'e dewe", di mana kalimat iklan tersebut seharusnya berbunyi: "Monggo mas, dipun bayar pajegipun kangge mbangun daerahipun piyambak".

Penggunaan bahasa di kantong kolonisasi Wonomulyo memang memiliki variasi yang beragam, terutama dalam dialek dan kehalusan dalam bertutur kata. Perbedaan tersebut, saat ini masih dapat diidentifikasi dengan jelas. Keadaan inilah yang ikut memberikan kesan bahwa bahasa Jawa yang berkembang di Wonomulyo saat ini adalah bahasa Jawa yang kasar. 
Faktor Pendukung Keberlanjutan Bahasa Jawa di Wonomulyo

Keberlanjutan bahasa Jawa di Wonomulyo sangat dipengaruhi oleh penggunaan bahasa Jawa tersebut dalam kehidupan sehari-hari. Hasil pengamatan menunjukkan, umumnya murid-murid sekolah dasar yang diamati dalam berkomunikasi dengan sesamanya menggunakan bahasa Jawa dalam bentuk ngoko. Hanya sesekali mereka terdengar berbicara dalam bahasa Indonesia atau bahasa daerah lainnya. Ternyata bahasa Jawa digunakan dalam pergaulan sehari-hari dan juga digunakan dalam lingkungan keluarga. Aspek lain yang turut memperkuat fungsionalisasi bahasa Jawa adalah proses labelisasi dalam berbagai aspek kehidupan dengan menggunakan istilah-istilah Jawa. Proses labelisasi bahasa Jawa terus berlangsung secara nasional, tidak hanya pada daerah pengguna bahasa Jawa tetapi juga pada daerah-daerah bukan pemakai bahasa Jawa. Misalnya, Griya Taman Sari bukan perumahan Taman Sari, Graha Modern bukan rumah Modern, Puri Permata sari dan sebagainya. Hasil pengamatan di bebe'rapa desa fokus penelitian ditemukan pula lembaga-lembaga sosial yang diberi label bahasa Jawa. Misalnya Paguyuban Mardi Budaya di Bumiayu yaitu kelompok kesenian Jawa, kelompok pendengar pembaca dan pemirsa (klompencapir) Mayapada di desa Sumberejo, kelompok peternak Tanggulsari, Margodadi, dan Mekarsari, serta kelompok usaha mandiri Mugi Rahayu yang kesemuanya terdapat di desa Kebunsari.

\section{Kyai Ulem Jumengglung yang Dikeramatkan.}

Simbol-simbol komunikasi non verbal yang masih bertahan secara fungsional adalah bedug dan kentongan. Bedug merupakan alat komunikasi yang berhubungan dengan kegiatan ritual peribadatan, terutama sebagai alat yang memberikan tanda telah masuknya waktu shalat khususnya pada hari Jum'at, permulaan puasa Ramadhan, dan saat tibanya hari raya Idul Fitri maupun Idul Adha. Eratnya hubungan bedug dengan hal-hal yang bersifat ritual dan peribadatan, sehingga bedug biasanya ditempatkan di masjid-masjid atau langgar-langgar. Hampir dapat dipastikan bahwa di setiap masjid pada kantong kolonisasi Wonomulyo terdapat bedug sebagai salah satu kelengkapan masjid.

Di Desa Campurejo, kentongan digunakan untuk memanggil aparat desa. Selain itu, kentongan induk yang berada di desa ini dinamai Kyai Ulem Jumengglung dan ditempatkan di kantor desa. Kyai Ulem Jemengglung digunakan untuk mewartakan hal-hal penting untuk diketahui oleh seluruh penduduk desa, misalnya bila ada kematian, terjadi kebakaran, pencurian, atau perampokan yang memerlukan kewaspadaan dan kesiapsiagaan bersama. Kyai Ulem Jumengglung juga digunakan untuk memanggil atau mengumpulkan warga desa bila hendak diadakan bersih desa dan aktifitas desa lainnya yang bersifat massal. Penamaan kentongan yang dibuat pada tahun 1952 dengan sebutan Kyai Ulem Jumengglung mengandung nilai-nilai spiritual yang disakralkan. Penyakralan terhadap kentongan ini terlihat dari penamaan serta perlakuan penduduk desa terhadapnya. Sebagai benda pusaka, Kyai Ulem Jumengglung diletakkan pada tempat dan bangunan yang khusus dibuat untuk itu. Nama kentongan tersebut secara harfiah dalam bahasa Jawa mengandung makna bahwa kyai merupakan sebutan benda atau orang yang disakralkan dan mempunyai tuah. Ulem berarti undangan, ngulemulemi artinya mengundang atau memanggil. Sedangkan jumengglung diartikan sebagai suara yang menggelegar dan nyaring, sehingga dapat didengar oleh orang banyak terutama seluruh penduduk desa. Bagi penduduk Desa Campurejo, keberadaan Kyai Ulem Jumengglung memiliki arti yang penting sebagai media komunikasi massa non verbal.

\section{Kesenian Rakyat Kuda Kepang}

Di kantong kolonisasi Wonomulyo pernah berkembang dengan baik beraneka ragam jenis kesenian tradisional Jawa, seperti wayang kulit, wayang orang, kuda lumping atau kuda kepang, ketoprak, reyog, uyon-uyon, dan musik campursari. Keragaman seni tradisional berhubungan erat dengan keragaman sub etnis Jawa yang tinggal di daerah ini dengan karakteristik budayanya yang khas. Reyog misalnya, sebagai representasi dari cara berkesenian sub etnis Jawa yang berasal dari daerah Ponorogo dan sekitarnya. Wayang kulit dan wayang wong merupakan jenis kesenian yang berorientasi pada keraton dengan menggunakan bahasa Jawa halus. Wayang merupakan kesenian yang sarat nilainilai filosofis dan mengandung ajaran moral serta keteladanan bagi kehidupan sehari-hari orang Jawa. Wayang adalah sebuah epos kepahlawanan yang bersumber dari kitab Mahabarata dan Ramayana yang telah diberi muatan moral Islam oleh Sunan Kalijaga. Oleh karena itu, kesenian wayang menjadi kesenian yang bersifat sinkretis dan digemari oleh seluruh lapisan sosial orang Jawa tanpa melihat agama dan aliran kepercayaannya. 
Di desa Bumiayu, Paguyuban, Marsudi budaya berusaha melestarikan kesenian wayang, meskipun diakui terdapat beberapa kendala untuk mengembangkan seni pewayangan. Hambatanhambatan tersebut antara lain: (1) Semakin langkanya dalang yang mampu berbahasa Jawa halus dan terampil memainkan wayang, (2) Untuk pementasan wayang dibutuhkan biaya besar, karena melibatkan personil yang cukup banyak yang terdiri atas dalang, tenaga pengiring atau penabuh gamelan (niyaga), dan pesinden. Jumlah personil dalam pementasan wayang berkisar antara dua puluh lima sampai tiga puluh orang. (3) Terjadinya perubahan pola penggunaan bahasa dari bahasa Jawa ke bahasa Indonesia sebagai bahasa komunikasi lintas etnis. (4) Tumbuhnya hasil karya cipta seni yang diproduksi secara massal melalui rekaman dalam bentuk kaset dan compact disk (CD) mempermudah bagi para penikmat seni tradisional.

Di Wonomulyo, kesenian kuda kepang masih dipelihara dengan baik dan sering dipentaskan. Permainan kuda kepang dipentaskan pada tempat terbuka dan luas. Penonton tidak-disediakan tempat duduk, mereka cukup berdiri di sekeliling arena permainan. Sebelum tarian dimulai, dukun membakar kemenyan dan membaca manteramantera seraya meminta ijin kepada ruh-ruh halus yang disebut danyang atau indang agar berkenan memberikan tenaga bagi kuda-kuda yang akan digunakan. Melalui lecutan cambuk sebagai tanda bahwa setiap pemain telah siap untuk menaiki kuda masing-masing dibarengi dengan bunyi musik, para penari masuk ke gelanggang dengan menaiki kudanya. Pada awal pertunjukan musik ditabuh dengan suara pelan, monoton, dan agak membosankan, sedangkan para penari menunggang dan memacu kudanya menurut pola sesuai dengan irama musik pengiring. Selanjutnya ketika musik pengiring semakin rancak, cepat, dan dinamis, kuda-kuda akan bergerak dengan lebih cepat berlari mengelilingi arena permainan. Dalam suasana yang demikian ini beberapa orang pemain akan mengalami trance karena dimasuki ruh halus atau danyang. Penari kuda kepang yang dalam keadaan trance dapat melakukan perbuatan-perbuatan aneh dan luar biasa yang tidak mungkin dapat dilakukan oleh orang-orang yang berada dalam keadaan sadar. Pemain yang tengah mabuk akan berperilaku sesuai dengan danyang atau indang yang merasukinya. Selama pemain kuda kepang dalam keadaan trance, musik pengiring harus ditabuh dengan irama yang lebih cepat dan rancak agar pemain yang telah dirasuki danyang atau indang ini tidak marah.
Pemain yang marah mereka akan memberontak dan menendang pemain musik sekan-akan kuda binal yang tak terkendali.

Dalam permainan kuda kepang, ada beberapa pantangan yang perlu dihindari oleh penonton maupun penyelenggara, misalnya dilarang mengenakan baju berwarna merah karena dikhawatirkan akan menjadi sasaran kemarahan pemain yang sedang mabuk. Selain itu, pemain tidak boleh melihat kaca beserta serpihannya, sebab dikhawatirkan akan dimakan oleh para pemain yang sedang mabuk sehingga dapat melukai mereka. Puncak permainan kuda kepang yakni ketika dukun menyadarkan kembali pemain yang dalam keadaan trance melalui mantra-mantra dan meniupkannya ditelinga mereka. Berbeda halnya dengan tradisi sayyang patudu kesenian orang Mandar yang bernuansa Islami, kesenian kuda kepang yang berkembang pada komunitas Jawa Wonomulyo secara tradisional masih diwarnai kepercayaan Jawaisme yang bersifat sinkretik.

\section{Rumah Bangunan Tempat Tinggal dan Simbol Status.}

Bangunan rumah pada desa-desa Jawa kantong kolonisasi Wonomulyo terdiri atas beberapa tipe utama, yaitu: tipe limasan, serotong, dan klabangnyender. Kodiran (2004) menyebutkan, ketiga tipe rumah tersebut merupakan sebagian tipe rumah menurut gaya arsitektur tradisional Jawa. Selain ketiga tipe tersebut, pada desa-desa fokus penelitian juga terdapat tipe rumah joglo dan tipe-tipe rumah menurut gaya arsitektur modern. Model rumah joglo adalah gaya bangunan rumah tempat tinggal yang pada umumnya telah dipengaruhi oleh budaya kota. Karena itu rumahrumah dengan arsitektur modern tersebut lebih banyak terdapat pada daerah-daerah urban dan sub urban yang telah atau sedang mengalami proses pengkotaan. Meskipun demikian, di desa-desa yang jauh dari kehidupan kota, kadangkala juga dijumpai bangunan tempat tinggal dengan model sejenis. Hal ini menunjukkan bahwa penghuni atau pemiliknya mempunyai tingkat mobilitas yang tinggi, sehingga perbedaan jarak dan ruang antara desa dan kota menjadi semakin sempit.

Bedasarkan pengamatan pada desa-desa Jawa di kantong kolonisasi Wonomulyo, sebagian besar bangunan tempat tinggal penduduk desa adalah rumah tipe Jawa, dalam bentuk tipe limasan, srotong, klabangnyender, maupun joglo. Rumah joglo biasanya dikaitkan dengan status dan peran seseorang dalam masyarakat. Rumah joglo secara 
tradisional merupakan tempat tinggal para elit desa yang dalam struktur kehidupan sosial desa mereka merupakan lapisan sosial atas. Mattulada (Koentjaraningrat, 2004) mengemukakan bahwa rumah joglo dapat disamakan dengan sao raja atau balla lompo pada budaya orang Bugis atau orang Makassar.

\section{Sistem Sosial}

Kelompok orang-orang Jawa di kantong kolonisasi Wonomulyo sebagai fakta sosial di tanah Mandar mulai terbentuk sejak tahun 1937, yang kemudian secara teritoris tergabung dalam satu kesatuan sosial pada desa-desa Jawa yang dibentuknya. Justifikasi teritoris secara formal ditetapkan tahun 1950 ketika pemerintah mengubah nama kantong kolonisasi Mapilli menjadi Wonomulyo, kemudian pada tahun 1960 Wonomulyo ditetapkan sebagai sebuah kecamatan yang identik dengan kumpulan desadesa dan kampung-kampung Jawa. Fenomena ini mempertegas bahwa kelompok orang-orang Jawa di Wonomulyo dengan latar belakang budaya dan adat istiadatnya merupakan satu sistem sosial tersendiri yang dapat dibedakan dengan sistem sosial lainnya yang ada di Tanah Mandar. Penamaan dan labelisasi desa dan dukuh dengan menggunakan namanama dalam bahasa Jawa dan sebutan "kampung Jawa" yang sering diucapkan oleh orang-orang Mandar, Bugis, Makassar, dan kelompok-kelompok etnis lainnya untuk menunjuk Wonomulyo, mempertegas fakta sosial tersebut. Di sisi lain, pembenaran teoritis kelompok orang-orang Jawa pada kantong kolonisasi Wonomulyo sebagai suatu sistem sosial adalah terpenuhinya prinsip-prinsip struktural yang mampu menghasilkan keseluruhan kumpulan institusi sosial pada lintas ruang dan waktu yang berbeda dengan lingkungan sosial yang mengitarinya. Giddens (1995) mengidentifikasi tiga prinsip struktural yang berlaku dalam suatu sistem sosial, yaitu: adanya asosiasi dan pertautan antara sistem sosial dengan teritori dan lokalitas khusus, sistem norma dan pola-pola budaya, serta munculnya perasaan tentang semacam identitas bersama yang timbul dalam kesadaran praktis dan diskursif yang tidak lagi memerlukan permufakatan nilai.

Pengamatan pada komunitas orang-orang Jawa di kolonisasi Wonomulyo sebagai suatu sistem terlihat dengan jelas struktur sosial dan berbagai bagiannya yang sangat berbeda dengan struktur sosial komunitas lain yang ada di sekitarnya. Pandangan hidup orang Jawa yang kemudian diwujudkan dalam sistem tata nilai dan tata moral merupakan konsepsi abstrak yang menjadi panduan dalam bertindak mengenai apa yang seharusnya dilakukan dan apa yang seharusnya dihindari. Pandangan dan nilai-nilai hidup orang Jawa di kantong kolonisasi Wonomulyo yang diwarisi secara turun temurun dan telah melembaga dalam nilai-nilai sabar, rila, narima, rukun dan tepa selira kemudian membentuk pola-pola budaya yang mendasari setiap tindakan sosial yang dilakukan oleh orang-orang Jawa di daerah ini. Interaksi sosial dalam kehidupan sehari-hari terjadi karena adanya persoalan-persoalan pokok yang dihayati bersama oleh para aktor, sehingga mereka akan melakukan proses interaksi dan komunikasi, baik interaksi dan komunikasi yang dilakukan dalam sistem sosial yang berangkutan maupun dengan lingkungan sosial lain yang mengitarinya. Penggunaan bahasa yang berbeda oleh orang-orang Jawa sebagai alat komunikasi untuk merespon lingkungan sosial yang dihadapinya, secara teoritis relevan dengan pandangan Doom dan Lammers di atas. Hal ini terlihat ketika orang Jawa berbicara dengan sesama orang Jawa maka ia akan berbicara dalam bahasa Jawa. Bagi orang Jawa, akan terasa tidak pas dan kurang etis bila berkomunikasi dengan sesama orang Jawa tidak menggunakan bahasa Jawa. Mereka akan dipandang sebagai orang yang tidak tahu unggah- ungguh dan tata krama. Tetapi apabila berkomunikasi dengan orang Bugis, Mandar, atau Makassar, sedapat mungkin ia akan berbicara dalam bahasa Indonesia, meskipun menggunakan struktur kalimat yang kurang tepat.

Berdasarkan temuan empiris, faktor lain yang dapat dikatakan sebagai perekat sehingga sistem sosial yang bercorak 'kejawaan' pada kantong kolonisasi Wonomulyo adalah adanya kesadaran kolektif dalam bentuk sistem kepercayaan yang dianut secara turun temurun yang dikenal dengan istilah Kejawen. Kepercayaan ini terutama berdasarkan kepercayaan animisme dengan pengaruh Hindu-Budha, dan agama-agama lainnya yang berkembang sesudahnya. Kepercayaanya menjadi bersifat sinkretis yang memperlakukan semua budaya dari luar dengan cara menyerap dan menafsirkannya menurut nilai-nilai Jawa, sehingga kepercayaan seseorang kadang-kadang menjadi kabur. Keadaan ini menjadi pendorong bagi orangorang Jawa yang cenderung lebih menekankan bagian Jawa dari warisan kultural mereka dan menganggap afiliasi keagamaan (dalam arti yang formal) hanya sebagai suatu hal yang sekunder. 
Inti kejawen, terletak pada ajaran tentang sangkan paraning dumadi dan kesadaran kolektif setiap orang Jawa atas falsafah melu memayu hayuning bawana. Kejawen merupakan ajaran yang menekankan agar setiap manusia menyadari asal usul kejadiannya yang berasal dan diciptakan dari tanah dan kelak ia akan kembali menyatu dengan tanah pula. Secara aplikatif, ajaran ini mengajarkan bahwa dalam melangkah diri ke dunia, seseorang harus menggunakan ide dan prinsip yang sama, karena hal-hal yang besar bermula dari hal-hal yang kecil, serta dunia yang penuh sesak ini hanya berasal dari dua orang saja, yaitu "bapa Adam" dan "ibu Hawa" yang kejadiannya berasal dari tanah. Tanah sebagai asal mula kejadian manusia (sangkaning manungsa) harus dipandang sebagai sesuatu yang suci, yang harus dihormati, dipelihara, didekati, dan tidak boleh dijauhi.

Konsep tempat tinggal (rumah) pada orangorang Jawa yang umumnya berlantai tanah atau semen yang menyatu dengan tanah disertai dengan atap gentengyang juga berasal dari tanah merupakan refleksi penyatuan manusia dengan asal kejadiannya. Atap genteng bukan merupakan simbol status, melainkan perwujudan dari laku penghormatan alam bawah sadar manusia Jawa terhadap asal mula kejadiannya. Selain itu, penghormatan lainnya terhadap tanah diujudkan dalam bentuk ritual tedak siti, saur tanah, ruwat bumi, dan sedekah bumi yang diantaranya masih tetap dipertahankan secara aktif oleh komunitas Jawa Wonomulyo. Tedak siti (tedak - menginjak, sitz'=tanah), merupakan ritual siklus hidup yang diadakan ketika seorang anak baru pertama kalinya menginjakkan kaki di tanah. Upacara ini dimaksudkan agar anak kelak dapat selamat dan sentosa dalam mengarungi kehidupannya di muka bumi. Selanjutnya, ritual saur tanah sebagai upacara peringatan seribu hari kematian sering disamakan dengan upacara nyewu, sidekah atau nguwis-uwisi (penutup dalam ritual siklus hidup).

Dalam relasi sosial, etika Jawa menekankan ketergantungan lahir dan batin, diri dan orang lain. Seseorang tidak akan selamat jika tidak diijinkan oleh lingkungannya, termasuk orang lain. Seseorang yang ingin selamat harus memperhatikan kesejahteraan umum. Setiap orang harus rumangsa (merasa dan sadar) bahwa dirinya adalah bagian dari orang lain dan lingkungannya, sehingga kesadaran ini dapat menjadi basis dari rasa rukun dan harmoni sosial. Rumangsa berhubungan dengan perasaan persaudaraan dan empati, yang berbeda dengan rasa (intuitif) yang berhubungan dengan kehidupan batin dan keselamatan personal. Sebagai sesama migran, orang-orang Jawa di Wonomulyo merasa senasib sepenanggungan, sehingga dalam kehidupan sehari-hari perlu tolong menolong, bantu membantu satu sama lain. Sikap Rumangsa (sadar) dalam kelompok pendatang harus menjaga keselarasan sosial dengan lingkungan sekitarnya, sehingga tercipta dunia yang indah, damai, dan makmur (memayu hayuning bawana) dalam kehidupan bersama dan antar sesama.

\section{Struktur Sosial}

Komunitas Jawa di kantong kolonisasi Wonomulyo menggambarkan apa yang dimaksud oleh neofungsionalisme tentang masyarakat kombinasi tiga struktur sosial dengan masingmasing karakteristiknya menjadi kekuatan internal yang menggerakkan kumpulan orang-orang Jawa sebagai suatu sistem sosial dapat bertahan, meskipun secara empiris harus pula bersinggungan dengan sistem sosial yang berbeda. Fakta ini memungkinkan terjadinya dua kekuatan berbeda yang berinteraksi secara simbiosis yaitu kekuatan yang berasal dari dalam sistem sosial yang bersangkutan maupun kekuatan yang berasal dari lingkungannya.

Persinggungan pandangan hidup dan tata nilai dengan sistem sosial yang berbeda, akan menimbulkan penyimpangan sosial menurut sudut pandang sistem sosial yang bersangkutan, tetapi sekaligus penyimpangan sosial tersebut akan memberikan peluang yang luas terjadinya kontrol sosial. Penggunaan bahasa Jawa baik lisan maupun tulisan dalam pergaulan sehari-hari pada komunitas Jawa di kantong kolonisasi Wonomulyo yang sering mengabaikan bentuk bahasa Jawa baku dianggap sebagai suatu bentuk penyimpangan terhadap tata nilai, sopan santun, unggah-ungguh, serta etiket pergaulan. Begitu pula pencampuran dan penggunaan dwi bahasa (Jawa dan Indonesia) secara bersama-sama dalam pergaulan sehari-hari antara sesama orang Jawa terutama terhadap mereka yang secara sosial memiliki status tinggi dianggap tidak pantas dan ora Jawani (tidak seperti orang Jawa). Sebaliknya, secara makro justru penggunaan dwi bahasa ini menjadi kekuatan integratif yang menyatukan masyarakat Wonomulyo sebagai suatu entitas. Kemampuan orang Jawa pada kantong kolonisasi Wonomulyo untuk menggunakan bahasa Jawa dan bahasa Indonesia secara bersama-sama, atau bahkan bahasa dari kelompok etnis tertentu mampu memfasilitasi hubungan dan kerjasama antara pelbagai kelompok etnis, sehingga dapat mencegah terjadinya kesalahpahaman dalam 
pergaulan sosial. Pakar neofungsionalis, Alexander dan Colomy (Ritzer, 2003) menyimpulkan bahwa bahwa kemampuan penggunaan multi bahasa yang dimiliki oleh orang-orang Jawa di Wonomulyo adalah hasil dari proses interpenetrasi atas sistem sosial, yang selain menghasilkan keteganganketegangan sekaligus juga merupakan sumber perubahan sosial pada komunitas Jawa di kantong kolonisasi Wonomulyo.

\section{Proses Sosial}

Mengamati sistem sosial komunitas Jawa pada kantong kolonisasi Wonomulyo menurut perspektif 'Teori Sistem Umuni yang dikembangkan oleh Luhmann yang di dalamnya terdapat berbagai sistem kode yang digunakan. Dalam komunikasi dan interaksi sosial, sistem kode berupa bahasa yang digunakan, baik verbal maupun non verbal, mengandung makna yang hanya dapat diketahui oleh masing-masing aktor yang terlibat. Misalnya, penggunaan kentongan sebagai alat komunikasi non verbal dengan jumlah bilangan tertentu untuk peristiwa yang berbeda-beda adalah sistim kode yang dikembangkan oleh komunitas Jawa. Arti dan makna bunyi kentongan akan segera diketahui oleh orang-orang Jawa di kantong kolonisasi Wonomulyo berdasarkan pengetahuan yang telah terinternalisasi secara turun temurun.

Selain itu, bahasa sebagai sistem kode yang berkembang di kantong kolonisasi Wonomulyo dan menjadi alat komunikasi adalah corak bahasa Jawa khas Wonomulyo yang merupakan perpaduan dari berbagai sub varian bahasa Jawa menurut latar belakang daerah asal kolonis yang dipadu bahasa Indonesia dengan dialek lokal. Hal ini dapat dilihat pada iklan layanan masyarakat yang berisi ajakan bagi masyarakat Wonomulyo untuk memenuhi kewajibannya dalam membayar pajak. Perubahan bahasa sebagai alat atau simbol komunikasi dan interaksi yang terjadi di kantong kolonisasi Wonomulyo merupakan hasil dari suatu proses dialektis antara kekuatan atau unsur-unsur internal pada sistem sosial komunitas Jawa dengan kekuatan eksternal yang berasal dari lingkungannya. Dengan demikian, bahasa sebagai simbol dalam berkomunikasi tidak lain adalah sebagai suatu benda atau kejadian yang artinya dilekatkan oleh orang yang menggunakanya secara kolektif. White (Kaplan \& Manners, 2002) menyatakan bahwa kaitan antara bunyi kata dengan arti atau makna yang kita sadari mengandung sifat simbolik dari komunikasi antar manusia. Kaitan antara sepatah kata dengan re/erennya sebenarnya telah tertanam dalam sistem syaraf kita melalui pengkondisian dengan proses sosialisasi dan internalisasi, sehingga apabila kita mereaksi kata tersebut seolah-olah arti itu sudah terkandung dalam bunyi kata tersebut.

Proses-proses sosialmelaluisimbolisasihampir mencakup seluruh segi kehidupan komunitas Jawa Wonomulyo. Dalam sistem kepercayaan dan religi, orang Jawa mengembangkan konsep slametan yang dianggap sebagai inti dari agama Jawa (Beatty, 2001). Melalui ritual slametan, orang Jawa menekankan untuk menggapai ketentraman batin, keselarasan dan keseimbangan, manusia harus memiliki sikap nrima terhadap segala peristiwa yang terjadi sambil menempatkan individu di bawah masyarakat dan masyarakat di bawah semesta alam. Tujuan utama dalam hidup adalah slamet yaitu terciptanya keselarasan atau keseimbangan kosmik yaitu antara kehidupan makrokosmos dan mikrokosmos. Dipandang dari sudut teori sistem umum semua sistem simbol tersebut, merupakan elemen dasar yang diciptakan sendiri oleh sistem sosial orang Jawa pada Wonomulyo. Luhmann (Turner, 1990) menyebutnya dengan konsep autopoietic yang berlandaskan self organizing dan self referential di mana sebuah sistem sosial yang mengorganisasikan batas-batasnya sendiri, mengorganisasikan struktur internalnya sendiri, serta mengacu pada dirinya sendiri sehingga dapat mempertahankan eksistensinya.

\section{Keberlanjutan Sistem Sosial}

Keberadaan migran Jawa di kantong kolonisasi Wonomulyo ternyata lebih didasarkan atas alasanalasan ekonomi dari pada alasan-alasan lainnya. Berdasarkan latar belakang ekonomi itu, ditambah dengan kerasnya kehidupan sebagai kolonis yang harus trukah, membangun desa, memulai dan menata kehidupannya yang baru di tanah seberang, mereka terpaksa mengesampingkan aspek kesenian dan budaya yang dibawa dari tanah leluhurnya. Hal ini malah justru akan menjadi salah satu penyebab besarnya kerinduan dan ketertarikan kepada kampung halaman di kalangan generasi-generasi berikutnya. Fenomena ini ditandai dengan besarnya perhatian anak keturunan para kolonis terhadap kesenian Jawa. Mereka berusaha melaksanakan tata krama, unggah-ungguh, serta etiket dalam pergaulan menurut adat Jawa, dan melaksanakan upacara-upacara adat Jawa walaupun mereka lahir dan dibesarkan di Tanah Mandar.

Dalam beradaptasi dengan lingkungannya, konsep nrima yang dimiliki oleh orang-orang Jawa menjadikannya rukun dan tenggang rasa 
dengan lingkungan sosial lain yang berbeda secara kultural, baik sesama warga para keturunan kolonis maupun dengan masyarakat setempat. Namun, model adaptatif yang diterapkan oleh orang-orang Jawa di tanah seberang sebenarnya justru semakin mengentalkan kejawaanya dan mempertegas bahwa orang Jawa memiliki kultur yang berbeda. Soeseno dan Susilo (1985) menyatakan bahwa sekalipun orang Jawa mau menyesuaikan dengan daerah baru, tetapi sesungguhnya mereka cenderung resisten dengan nilai-nilai Jawanya, sehingga orang Jawa memandang kultur lain sebagai kultur yang berbeda, bukan sebagai bagian dari dirinya. Hal ini sangat berbeda dengan pandangan hidup orang Batak, orang Minang, dan orang Bugis yang menganggap alam rantau (tanah seberang) sebagai perluasan dan bagian integral dari kampung halamannya. Hal tersebut menyebabkan ketiga kelompok etnis ini cenderung memiliki tingkat kemampuan yang lebih baik untuk menyesuaian diri secara total dengan kultur tanah seberang dan memandang kultur tersebut sebagai bagian dari dirinya juga, bukan sebagai sesuatu yang asing.

Berbeda halnya komunitas desa Jawa di Kuching (Serawak) misalnya, meskipun jauh di tanah seberang, namun mereka masih tetap mempertahankan dan mereproduksikan simbolsimbol budayanya seperti penggunaan bahasa Jawa dalam percakapan sehari-hari, bahkan mereka menciptakan gamelan meskipun secara substansial berbeda dengan apa yang ada ditanah leluhurnya (Sairin, 2002). Hal yang sama juga ditemukan pada desa-desa Jawa di kantong kolonisasi Wonomulyo. Latar belakang dan pola migrasi yang bersifat kelompok (organized migration) dan massal melalui program kolonisasi lebih menjamin terciptanya perasaan aman, baik secara sosial maupun kultural. Selanjutnya dengan pola pemukiman penduduk migran yang dikembangkan oleh pemerintah kolonial Hindia Belanda yakni dengan mengelompokkan menurut daerah asal, sehingga memberikan ruangyang luas terhadap keberlanjutan sistem sosial komunitas Jawa di daerah ini.

Dampak positif dari dimensi interaksional antara komunitas Jawa, Bugis, dan Mandar adalah terjadinya pertukaran bahasa antar etnis. Meskipun pada tiga desa yang menjadi fokus pengamatan (Kebunsari, Sumberrejo, dan Campurrejo) orangorang yang ada di dalamnya mengaku menggunakan bahasa Indonesia di tempat-tempat umum, tetapi juga tampaknya terjadi pula pertukaran bahasa antar etnis tertentu terutama bagi mereka yang telah lama bermukim di ketiga desa fokus pengamatan.
Di ketiga desa ini, bahasa Jawa menjadi bahasa yang paling banyak digunakan oleh penduduk desa dalam berkomunikasi dengan sesamanya dan merupakan bahasa pilihan yang paling banyak dipelajari oleh komunitas Bugis, Mandar, Makassar dan sebagainya.

Pada dimensi kultural, dampak interaksi antar etnis pada kantong kolonisasi Wonomulyo adalah terjadinya persentuhan budaya yang memberikan peluang teciptanya suatu proses akulturasi yang intens. Pertukaran budaya antara etnis Jawa dan etnis lain yang mengitarinya hampir terjadi dalam berbagai aspek kehidupan meski dilakukan secara selektif terhadap bagian-bagian budaya lokal yang dapat diadopsi, sekaligus mencoba meneguhkan identitas budaya etnisnya sendiri. Dalam kehidupan ekonomi, terutama dalam bidang pertanian, orangorang Jawa secara tradisional cenderung terpusat pada pola pertanian budi daya lahan basah dan bersifat subsisten (Geertz, 1963). Orang-orang Jawa Wonomulyo kini mulai mengadopsi budi daya tanaman perkebunan komoditi eksport khususnya tanaman coklat (kakao) yang banyak diusahakan oleh penduduk lokal.

Sisi penting dalam temuan penelitian ini adalah, arah interaksi, adaptasi, dan akulturasi yang terjadi pada masyarakat kantong kolonisasi Wonomulyo. Ternyata arah interaksi yang terjadi selama bertahun-tahun lebih mengarah pada pembentukan sistem sosial 'kejawaan'. Di desadesa Jawa pada kantong kolonisasi Wonomulyo berkembang lembaga-lembaga dan pranata-pranata sosial yangbersifat'kejawaan'baikyangberhubungan dengan aspek ekonomi, sosial, budaya, dan agama. Penamaan lembaga-lembaga • inipun bercorak kejawaan seperti lembaga Klompencapir Mayapada di desa Sumberejo, kelompok peternak Tanggulsari, Mekarsari, Margodadi, dan Mugirahayu, kelompok P3A (Perkumpulan Petani Pemakai Air) Baru Muncul dan Rawamangun di desa Kebunsari, serta kelompok-kelompok usaha mandiri, dan paguyuban Marsudi Budaya di Bumiayu. Temuan penelitian yang menarik lainnya ternyata lembagalembaga tersebut dapat mewadahi aktifitas individuindividu dari beragam etnik yang memiliki profesi dan pekerjaan yang sama. Melalui pranata-pranata sosial ini akan tercipta pola hubungan simbiosis mutualistis yang saling menguntungkan.

\section{PENUTUP}

Berdasarkan pada pokok penelitian dan hasil penelitian beserta pembahasannya dapat diambil beberapa kesimpulan penelitian. Pertama, struktur 
sosial yang berkembang di kantong kolonisasi Wonomulyo mengombinasikan antara struktur masyarakat komunal, masyarakat agraris, dan struktur otoritas desa. Kedua, pola migrasi dan tata ruang pemukiman migran Jawa di kantong kolonisasi Wonomulyo merupakan salah satu faktor yang ikut memperkuat keberlangsungan simbolsimbol etnisitas serta sistem sosial budaya Jawa di tanah seberang. Ketiga, persinggungan migran Jawa dengan lingkungan sosial budaya yang mengitarinya memungkinkan terjadinya penyerapan dan penyesuaian nilai-nilai budaya lokal secara timbal balik yang terwujud dalam dimensi interaksional, struktural, dan kultural. Keempat, pranata-pranata tradisional dan simbol-simbol etnisitas yang masih berlaku secara fungsional dapat menjadi saluran yang efektif untuk mewariskan dan mentransformasikan nilai-nilai sosial budaya, sehingga keberlanjutan sistem sosial yang bercorak 'kejawaan pada kantong kolonisasi Wonomulyo dapat bertahan.

\section{Ucapan Terima Kasih}

Syukur Alhamdulillah kami panjatkan kehadirat Tuhan yang telah menganugerahi kepada kami kesempatan dan kesehatan serta keterbukaan pikiran sehingga tulisan ini bisa diselesaikan. Kepada komunitas Jawa Wonomulyo Sulawesi Barat yang turut memberi sumbangan ide dan informasi demi terwujudnya tulisan ini. Secara lebih khusus, kami juga menyampaikan terima kasih kepada pihak redaktur jurnal Al-Qalam Balai Penelitian dan Pengembangan Agama Makassar yang telah berkenan memuat tulisan ini. Semoga Tuhan memberkati kita semua. Amin.

\section{DAFTAR PUSTAKA}

Alatas, S.H. 1988. 'Mitos Pribumi Malas: Citra Orang Jawa, Melayu dan Fipina dalam Kapitalisme Koionial'. Jakarta: LP3ES.

Andi-Lolo, T.R. 1986. 'Transmigration and Rural Development in Indonesia'. Unpublished Disertation. Australia: Universty of Queensland.

Beatty, A. 2001. 'Varieties of Javanese Religion. Terjemahan oleh Saefudin dan Ahmad Fedyani. Jakarta: Rajagrafindo Persada.

Geertz, C. 1963. 'Agriculture Involution: The Processes of Ecological Change In Indonesia'. Berkeley: The University of California Press.
Giddens, A. 1995. "The Constitution of Society: The Outline of the Theory of Structuration. UK: Polity Press Cambridge.

Hamzah, A. 2000. 'Pola Asuh Anakpada Etnik Jawa Migran dan Etnik Mandar (Studi Budaya Lokal dengan Pendekatan Etnometodologi, Interaksi Simbolik, dan Analogi Model Kasper pada Pengasuhan Anak)'. Disertasi. Surabaya: Universitas Airlangga.

Kaplan, D. \& Manners, R.A. 2002. 'The Theory of Culture'. Diterjemahkan oleh Landung Simatupang. Jogjakarta: Pustaka Pelajar.

Karim, A. 2006. 'Sejarah Transmigrasi'. Diakses melalui http.//www.nakertrans. go.id

Koentjaraningrat. 2004. Manusia dan Kebudayaan di Indonesia. Jakarta: Djambatan.

Levang, P. 2003. Ayo Ke Tanah Sabrang, Transmigrasi di Indonesia. Terjemahan oleh Sri Ambar Wahyuni Prayogo. Jakarta: Kepustakaan Populer Gramedia.

Lukman. 2000. 'Pemertahanan Bahasa Warga Transmigran Jawa di Wonomulyo Polmas serta Hubungannya dengan Kedwibahasaan dan Faktor-faktor Sosial'. Disertasi. Makassar: Universitas Hasanuddin.

Mulder, N.1999. 'Inside Southeast Asia: Thai, Javanese, and Filiphino Interpretation of Everyday Life'. Terjemahan oleh Satrio Widiatmoko. Yogyakarta: Gramedia Pustaka Utama.

Ritzer, G. 1992. 'Sociology: A Multiple Paradigm Science'. Terjemahan oleh Alimandan. Jakarta: Raja Grafindo Persada.

Sairin, S. 2002. 'Perubahan Sdsial Masyarakat Indonesia'. Yogyakarta: Pustaka Pelajar.

Soelaiman, M.M. 1998. 'Dinamika Masyarakat Transisi: Mencari Alternatif Teori Sosiologi dan Arah Perubahan.' Yogyakarta: Pustaka Pelajar.

Soemardjan, S. 1996. 'Perubahan Sosial di Yogyakarta'. Yogyakarta: Gadjah Mada University Press.

Soeseno, F.V.M., \&Susilo. R. 1985. 'Etika Jawa dalam Tantangan. Yogyakarta: Kanisius.

Swasono, S.E. \& Masri Singarimbun. 1986. 'Transmigrasidilndonesia 1905-1985'. Depok: Universitas Indonesia Press.

Turner, J. H. 1991. "The Structure of Sociological Theory'. Belmont-California: Wardsworth Publishing Company 